\title{
Relationships between Riparian Buffer Widths and the Effects of Logging on Stream Habitat, Invertebrate Community Composition and Fish Abundance
}

\author{
P. E. Davies and M. Nelson \\ Department of Zoology, University of Tasmania, GPO Box 252C, Hobart, Tas. 7001, Australia.
}

\begin{abstract}
Impacts from the logging of Eucalyptus forest on stream habitat, macroinvertebrate abundance and diversity, and fish abundance were surveyed in Tasmania, Australia. Forty-five pairs of sites from 34 streams of $\geq 2.5 \mathrm{~km}^{2}$ catchment area were each sampled once during summer in the period 1990-92. Each site pair consisted of an 'impacted' site downstream of a logging treatment and an upstream or closely matched 'paired control' site. Site pair treatments encompassed two logging methods (cable and conventional) with a range of riparian buffer strip widths $(0-50 \mathrm{~m})$ and included unlogged controls. Differences between site pair variables were used as test statistics for the detection of logging impacts. Logging significantly increased riffle sediment, length of open stream, periphytic algal cover, water temperature and snag volume. Logging also significantly decreased riffle macroinvertebrate abundance, particularly of stoneflies and leptophlebiid mayflies, and brown trout abundance. All effects of logging were dependent on buffer strip width and were not significantly affected by coupe slope, soil erodibility or time (over one to five years) since logging. All impacts of logging were significant only at buffer widths of $<30 \mathrm{~m}$. Minimum buffer widths for eliminating logging impacts on stream habitats and biota are discussed.
\end{abstract}

Keywords: forestry, logging, streams, habitat, invertebrates, fish, buffers, effects, Tasmania, Australia.

\section{Introduction}

The multiple effects of logging on stream habitat, water quality and biota have been the subject of a substantial literature (Blackie et al. 1980; Campbell and Doeg 1989; Doeg and Koehn $1990 a, 1990 b$ ). Forestry operations have frequently been associated with increases in stream sediment load, changes in channel form, changes in stream hydrology and a variety of changes in stream faunal populations and communities. Logging operations that impinge on the stream channel directly or by the influence of road crossings are also associated with increases in sediment input and consequent declines in water quality and stream habitat integrity (e.g. Graynoth 1979; Culp and Davies 1983; Richardson 1985; Borg et al. 1988), leading to declines in abundance of invertebrates and fish. Removal or input of logging debris may also have a significant impact on stream channel form and faunal abundance and diversity (Lisle 1986). Decreases in shading associated with removal of riparian vegetation have been associated with increases in autocthonous primary production (Murphy et al. 1981; Noel et al. 1986) and production at higher trophic levels, provided instream habitat is not altered deleteriously (Murphy et al. 1986). Decreases in shading may also significantly alter the thermal regime of a stream flowing through a logged catchment (Ringler and Hall 1975; Noel et al. 1986), with a range of potential biological effects.

Several methods are used in forestry management to mitigate the impact of logging on streams. These include the use of riparian 'buffer' strips of natural forest with width prescriptions related to stream size (Cameron and Henderson 1979; Clinnick 1985), patch harvesting, siting 
and design of roads and road crossings to minimize sediment inputs, and restrictions to logging activities in relation to coupe slope and soil type. A range of these methods are incorporated into the planning of forestry operations in Australia and are incorporated into a number of guidelines or codes of practice adopted by the industry (e.g. Anon. 1993). Despite this, little work has been reported specifically examining the efficacy of these management methods in mitigating impacts on streams (Campbell and Doeg 1989).

Similarly, little has been published on the effects of Australian forestry operations on stream habitat quality or fauna (Campbell and Doeg 1989; Doeg and Koehn 1990b). Richardson (1985) reported impacts of road sedimentation associated with logging on stream macroinvertebrates. Borg et al. (1988) reported on the relationship between buffer strip width and both water quality and channel form in several Western Australian catchments, examining differences between streams without buffers or with buffers 50-200 $\mathrm{m}$ in width. Growns and Davis (1991) reported changes in stream invertebrate communities that were related to eight-year-old clearfelling operations in Western Australia. Barton and Davies (1993) described the relationship between stream pesticide concentrations, macroinvertebrate drift and buffer strip widths in Tasmanian forestry plantations. To date, no studies of the impacts of logging on stream habitat and associated fauna have been published in Australia that specifically address the issue of buffer strips and their utility.

The Tasmanian Forestry Commission has published a code of practice (Anon. 1993) that delineates the width and management of buffer strips for streams of different catchment sizes. The code also prescribes logging practices in relation to coupe slope and soil erodibility. All three factors may influence the relative impacts of logging operations on streams (Clinnick 1985). This code has been in widespread use in the industry during the last five years, whereas prior to this time protection of streams during forestry operations was largely managed on an $a d$ hoc basis.

This paper describes a study in which the effects of recent (1-5 year-old) logging operations on a number of stream habitat variables were examined in 34 streams. Relationships between changes in habitat variables are related to a number of variables describing the logging treatment. These include buffer strip width, logging method, coupe slope and soil erodibility. The abundance and community composition of stream riffle macroinvertebrates and the abundance of fish were also examined at 21 and 27 of the streams respectively and related to buffer strip width. Observed responses in stream habitat and biota are used to critically examine the minimum width of riparian forest buffers required to protect streams from short-term impacts induced by logging.

\section{Materials and Methods}

\section{Study Sites}

Study streams were chosen such that study reaches were adjacent to either a cable-logged or a conventionally logged coupe in previously unlogged Eucalyptus forest ('logged streams') or to unlogged dry or wet sclerophyll forest ('unlogged streams'). All streams were between 2.5 and $40.7 \mathrm{~km}^{2}$ in catchment area and were therefore defined as Class 2 streams under the Forest Practices Code (Anon. 1993), requiring 30-m riparian buffers when logged. The set of study sites chosen for each logging treatment contained a range of buffer strip widths (from 0 to $50 \mathrm{~m}$ ). All unlogged streams had riparian forest $>50 \mathrm{~m}$ in width. Streams were not included in the study set if they had road crossings adjacent to potential study reaches, variable coupe buffer widths, or the presence of other significant impacts upstream of potential study areas (e.g. quarries, tip sites, towns). In order to cover a wide range of conditions, streams were selected across a broad geographic area. The study streams are listed in Table 1 and their locations are indicated in Fig. 1.

Typically, two study sites were chosen on each study stream, with one site immediately upstream (paired 'control' site) of the treatment (logging or no logging) and one immediately downstream (paired 'treated' site). For 11 streams, comparable control sites were not available immediately upstream of the treatment, and a site on a nearby stream of similar size and morphology was selected as a paired control. In several cases, one upstream site served as a control for more than one downstream 'treated' site. Site pairs were selected so that no significant difference existed in the mean distance between sites for different logging or buffer width treatment groups (all $P>0.4$ by analysis of variance, overall mean $0.96 \mathrm{~km}$, range 
Table 1. Streams studied for logging impact, number of site pairs, variables assessed (h, habitat; $\mathrm{i}$, invertebrate; f, fish; see Table 2 for definitions), and location of the most downstream site in each stream (see Fig. 1)

\begin{tabular}{|c|c|c|c|}
\hline Stream & $\begin{array}{l}\text { Number of } \\
\text { site pairs }\end{array}$ & $\begin{array}{l}\text { Variables } \\
\text { assessed }\end{array}$ & $\begin{array}{l}\text { Location } \\
\text { (Universal Grid Reference) }\end{array}$ \\
\hline 1. Branchs Creek & 1 & $\mathrm{~h}, \mathrm{i}$ & 55GDQ745358 \\
\hline 2. Coles Creek & 1 & $\mathrm{~h}, \mathrm{f}$ & 55GDN513933 \\
\hline 3. Dale Brook & 1 & $\mathrm{~h}, \mathrm{i}, \mathrm{f}$ & 55GDP558874 \\
\hline 4. Farrells Creek & 1 & $\mathrm{~h}$ & 55GEQ573181 \\
\hline 5. Hogarth Rivulet & 4 & $h, \dot{i}, f$ & 55 GEQ512350 \\
\hline 6. Hot Springs Creek & 1 & $h, \dot{i}, \mathrm{f}$ & 55GDM885945 \\
\hline 7. Island Creek & 1 & $h, i, f$ & 55GEQ520082 \\
\hline 8. Joseph Creek & 1 & $\mathrm{~h}$ & 55GEQ575151 \\
\hline 9. Leven River & 3 & $h, f$ & 55GDQ018056 \\
\hline 10. Mackenzie River & 1 & $h, i, f$ & 55GEQ461329 \\
\hline 11. Martha Creek & 1 & $h, \dot{1}, f$ & 55GDP352922 \\
\hline 12. Memory Creek & 2 & $h, f$ & 55GEQ575145 \\
\hline 13. Mesa Creek & 1 & $h, i$ & 55GDM891926 \\
\hline 14. Milly Brook & 1 & $\mathrm{~h}$ & 55GEQ543123 \\
\hline 15. Montgomery Creek & 3 & $\mathrm{~h}$ & 55GEQ138426 \\
\hline 16. Mother Logans Creek & 1 & $\mathrm{~h}$ & 55GEQ928351 \\
\hline 17. Pig Run Creek & 1 & $h, f$ & 55GEQ440059 \\
\hline 18. Plenty River & 1 & $h, f$ & 55GDN873537 \\
\hline 19. Puzzle River & 1 & $\mathrm{~h}, \mathrm{f}$ & 55GDN894532 \\
\hline 20. Repulse River & 1 & $\mathrm{~h}, \mathrm{i}$ & 55GDN624891 \\
\hline 21. Russel River & 1 & $\mathrm{~h}, \mathrm{i}$ & 55 GDN778501 \\
\hline 22. Sales Rivulet & 2 & $h, \mathrm{i}, \mathrm{f}$ & 55GDP666832 \\
\hline 23. St. Josephs Creek & 1 & $h, \dot{i}, \mathrm{f}$ & $55 \mathrm{GCQ} 947345$ \\
\hline 24. Tombstone Creek & 2 & $h, \mathrm{i}, \mathrm{f}$ & 55GEQ574184 \\
\hline 25. Toranna Creek & 1 & $\mathrm{~h}$ & 55GCQ885218 \\
\hline 26. Unnamed tributary, Denison Creek & 1 & $\mathrm{~h}$ & 55 GDN774441 \\
\hline 27. Unnamed tributary, Russel River & 1 & $\mathrm{~h}$ & $55 \mathrm{GDN} 759500$ \\
\hline 28. Unnamed tributary, Russel River & 1 & $\mathrm{~h}$ & 55 GDN766523 \\
\hline 29. Unnamed tributary, Sumac Creek & 1 & $\mathrm{~h}$ & $55 G C Q 381415$ \\
\hline 30. Unnamed tributary, Talbots Creek & 1 & $\mathrm{~h}$ & $55 \mathrm{GCQ} 812159$ \\
\hline 31. Unnamed tributary, Tombstone Rivulet & 2 & $h, f$ & 55GEQ560167 \\
\hline 32. Unnamed tributary, Wentworth Creek & 1 & $\mathrm{~h}$ & 55GDP472238 \\
\hline 33. Wallaby Creek & 1 & $h, i, f$ & $55 \mathrm{GDQ} 728330$ \\
\hline 34. Weavers Creek & 2 & $h, i, f$ & 55GEQ316113 \\
\hline
\end{tabular}

$0.2-3.5 \mathrm{~km}$ ). Three logged sites $(5,18,19)$ were adjacent to logged pine (Pinus radiata) plantations. In all, 84 sites were chosen on 34 streams to produce 45 site pairs. All sampling was performed between November and March 1990-92 under base-flow conditions.

\section{Logging Treatments}

Stream site pair treatments were as follows: logged (39) and unlogged (6). Coupes were logged by cable-logging methods (skyline, high lead) at 15 treated sites, and 24 treated sites lay adjacent to coupes logged by conventional methods (clearfelling with ground-skidder log haulage). Logging was performed on only one side of the stream for all except 10 sites (on Streams 8, 11, 12, 15, 17, 18, 21, 25 and 26). For 


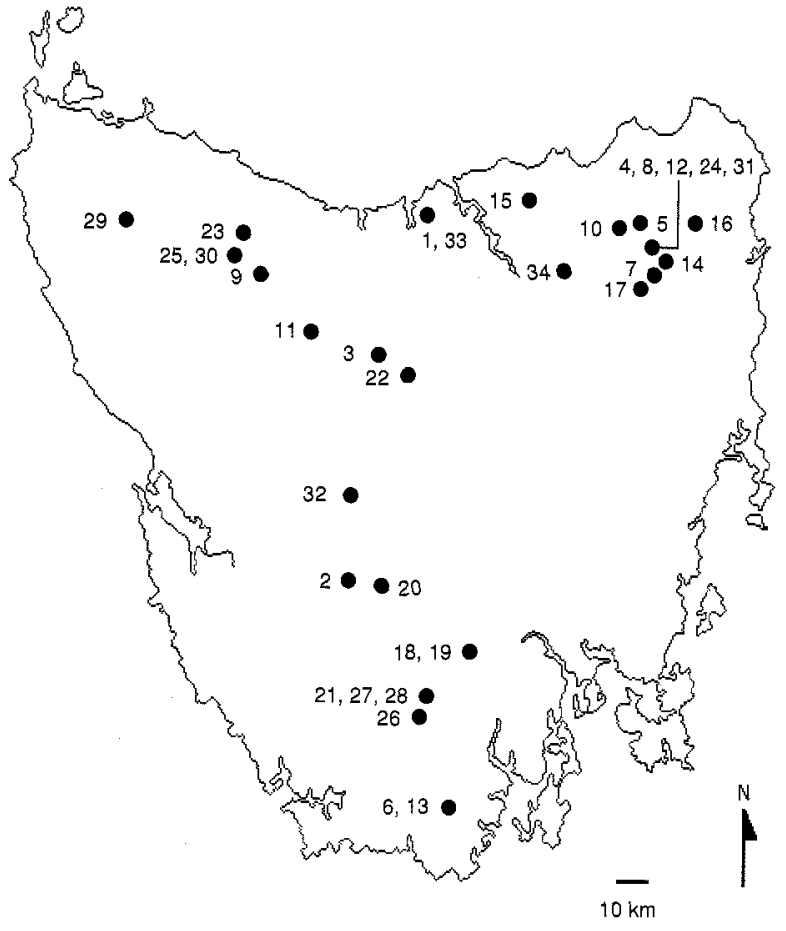

Fig. 1. Tasmania, showing locations of streams sampled in the study of logging impacts. Numbers refer to streams named in Table 1.

logged streams, mean buffer strip widths were calculated from three to five widths measured at evenly spaced intervals along the buffer. Soil erosion potential was classed as low, average or high according to the scheme detailed in Anon. (1993), on the basis of geology and slope. Twenty-four logging coupes were sited on soils of low to average erosion class and 15 on soils of high erosion class. All coupes ranged between one and five years of age (time between logging and sampling) and from 5\% to $70 \%$ majority slope. Only 11 streams had been logged $\geq 3$ years prior to sampling. Coupe areas ranged from 8 to 180 ha, with areas of coupe draining into the study streams ranging from 2 to 140 ha. Streams were selected so that no road crossings existed between site pairs.

\section{Measurement and Analysis of Habitat Variables}

A suite of variables was measured over a $100-\mathrm{m}$ reach of stream at all sites (Table 2), except that water temperature and conductivity were measured at only 31 sites ( $25 \operatorname{logged}, 6$ unlogged). All variables were potentially affected directly or indirectly by logging activity. All pairs of sites were sampled within a $48-\mathrm{h}$ period. Water temperature and conductivity were measured at paired sites within $2 \mathrm{~h}$ of each other, between 0900 and 1600 hours. The difference between the upstream and downstream values of each variable $(\Delta$ equals value downstream minus value upstream) was calculated and used as the test statistic.

\section{Sampling and Analysis of Invertebrates}

Ten Surber samples $\left(0.1 \mathrm{~m}^{2}\right.$ area each) were collected from a section of the most upstream riffle at each upstream and downstream site in 21 streams (Table 1). The samples were combined and stored in $4 \%$ formaldehyde. Each combined sample was then subsampled to 10-20\% according to Marchant (1989). Each subsample was manually sorted and identified to family level (except for oligochaetes and platyhelminths). The abundances per square metre of stream bed were then calculated for each taxon. The difference between the upstream and downstream abundance values of each taxon ( $\Delta$ equals abundance downstream minus abundance upstream) for each site pair was calculated and used as the test statistic for 


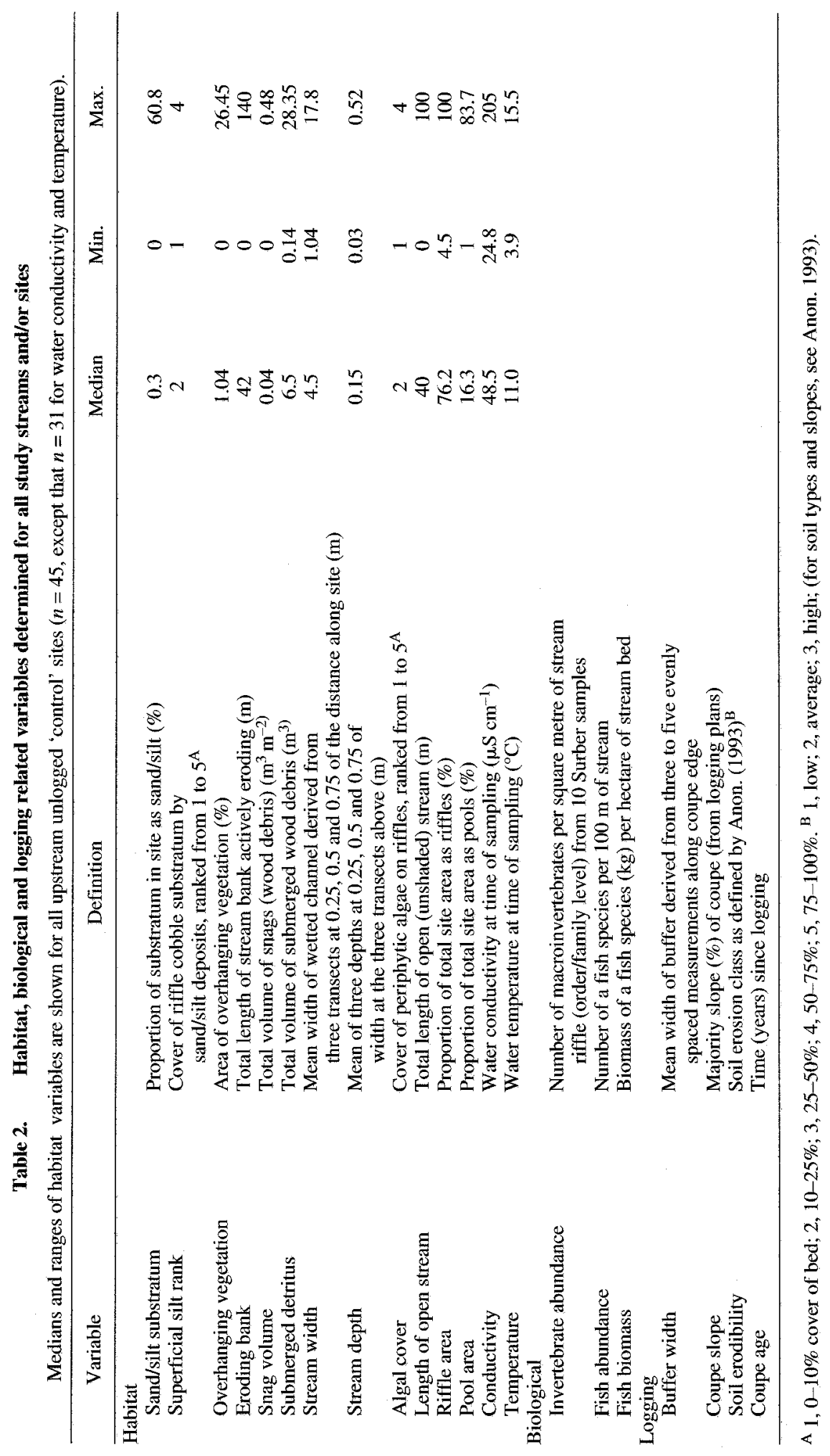


all taxa found to occur at at least one site within each site pair with a minimum abundance of $25 \mathrm{~m}^{-2}$ (a criterion selected to reduce the possibility of 'rare' taxa influencing the detection of differences associated with logging). In all, 57 taxa were found during the study, of which 26 satisfied the above criteria. Differences $(\Delta)$ were also calculated between the number of these taxa $\left(N_{\operatorname{tax}}\right)$ and the evenness $\left(N_{2}=\right.$ $1 / \Sigma \log p_{i}^{2}$, where $\left.\mathrm{p}_{\mathrm{i}}=n_{i} / \sum n_{i}\right)$ for all site pairs.

\section{Sampling and Analysis of Fish}

Fish populations were sampled by electrofishing at each site for 27 site pairs (Table 1). Three sequential passes of a backpack electroshocker (Smith-Root Model 12, $400 \mathrm{~W}$ pulsed direct current) were made in an upstream direction at each site, with fish captured from each run counted separately. All fish (except eels) were anaesthetized (with aqueous buffered tricaine methanosulfonate), measured (fork length to the nearest millimetre) and weighed prior to release. Counts were used to estimate abundance and biomass per $100 \mathrm{~m}$ of stream by the removal method (Zippin 1958; Higgins 1985).

\section{Statistical Treatment}

Intercorrelations between site pair $\Delta$ values were examined by Spearman's rank correlation for the habitat and biological variables as well as correlations between $\Delta$ values and logging treatment variables (SYSTAT Version 5.2, Corr routine, Wilkinson et al. 1992).

Complete nesting or orthogonality of treatment variables was not possible owing to either a lack of suitable sites or the exclusiveness of some treatment factors (e.g. cable logging and low slopes). Treatment covariates that could not be completely nested or incorporated into an orthogonal design were: time since logging (coupe age), coupe slope, coupe area and coupe soil erodibility (Table 2). Multiple analysis of variance (MANOVA; MGLH routine in SYSTAT) was performed on all $\log (x+100)$ transformed $\Delta$ values for habitat variables and for fish variables separately, with buffer width (control, $0-10,10-30,30-50 \mathrm{~m}$ ) as treatment and age since logging $(1,2,3-5$ years), coupe slope (\%) and soil erosion class (high, average, low) as covariates. Both univariate $F$ and multivariate $F$ (Pillai's criterion) were examined for significance (Tabachnik and Fidell 1989). One-way analysis of variance (ANOVA) was then performed on those variables found to have a significant univariate $F$ in the MANOVA.

For invertebrates, $\Delta$ abundance data were ordinated by non-linear hybrid multidimensional scaling (NLHMDS; SSH routine in PATN, Belbin 1993), using a Euclidian distance matrix for taxa selected according to the criteria cited above, identified to family level (with the exception of oligochaetes). Fifty random starts were made to the analysis and the solution with the lowest stress value selected (see Growns and Davis 1991).

Table 3. Spearman rank correlations between $n=45$, except that $n=31$ for underlined variables.

\begin{tabular}{lrrrrrr}
\hline & $\begin{array}{c}\text { Sand/silt } \\
\text { substratum }\end{array}$ & $\begin{array}{c}\text { Superficial } \\
\text { silt rank }\end{array}$ & $\begin{array}{c}\text { Overhanging } \\
\text { vegetation }\end{array}$ & $\begin{array}{c}\text { Eroding } \\
\text { bank }\end{array}$ & $\begin{array}{c}\text { Snag } \\
\text { volume }\end{array}$ & $\begin{array}{c}\text { Submerged } \\
\text { detritus }\end{array}$ \\
\hline Sand/silt substratum & 1 & & & & & \\
Superficial silt rank & $\mathbf{0 . 3 2 1}$ & 1 & & & & \\
Overhanging vegetation & -0.067 & -0.016 & 1 & & & \\
Eroding bank & 0.184 & $\mathbf{- 0 . 3 2 6}$ & -0.015 & 1 & & \\
Snag volume & 0.029 & 0.082 & -0.012 & -0.030 & 1 & \\
Submerged detritus & $\mathbf{0 . 5 0 3}$ & $\mathbf{0 . 4 0 7}$ & 0.004 & -0.081 & $\mathbf{0 . 2 9 1}$ & 1 \\
Stream width & 0.264 & 0.163 & -0.053 & 0.099 & -0.245 & 0.102 \\
Stream depth & -0.157 & -0.039 & -0.191 & -0.231 & 0.136 & 0.170 \\
Algal cover & 0.261 & $\mathbf{0 . 4 9 0}$ & 0.212 & -0.152 & 0.176 & 0.140 \\
Open stream length & 0.029 & $\mathbf{0 . 3 1 4}$ & -0.002 & -0.102 & $\mathbf{0 . 5 1 2}$ & $\mathbf{0 . 3 3 0}$ \\
Riffle area & -0.288 & -0.219 & -0.165 & 0.092 & -0.138 & $\mathbf{- 0 . 3 7 7}$ \\
Pool area & 0.219 & 0.117 & 0.213 & -0.055 & 0.118 & $\mathbf{0 . 3 3 8}$ \\
Conductivity & 0.127 & 0.132 & 0.017 & 0.086 & -0.058 & -0.063 \\
Temperature & -0.120 & 0.063 & 0.115 & 0.219 & 0.298 & -0.157 \\
\hline
\end{tabular}


Dimension scores were correlated with logging treatment variables, evenness and number of taxa and with $\Delta$ values- $\ln (x+1000)$ transformed-for individual invertebrate taxa by means of the PCC subroutine in PATN. Significance of the correlation coefficients derived from PCC were tested by performing 100 Monte Carlo randomizations of the data set (Faith and Norris 1989; Belbin 1993). If they were higher than $5 \%$ of those derived from the simulated data, they were considered to be significant at the 0.05 level. Kruskal-Wallis analysis of variance was then performed on $\Delta$ data for taxa significantly correlated with logging treatment variables, using riparian buffer width as treatments.

Dissimilarities were calculated from the family-level macroinvertebrate abundance data for each site pair, using the Bray-Curtis dissimilarity measure (Faith et al. 1987). Kruskal-Wallis analysis of variance was then performed on the Bray-Curtis values, with buffer width as treatment (control, 0-10, 10-30, $30-50 \mathrm{~m}$ ).

Statistical significance was inferred at the 0.05 level for all analyses, despite the use of multiple correlations and/or ANOVAs, in order to minimize the potential for Type II errors (Zar 1984).

Data are presented in the form of standard box plots (Helsel and Hirsch 1992; Wilkinson et al. 1992) with the median and interquartile range (IQR) represented by the centre line hinges, respectively. The whiskers extend to the inner fences at 1.5 times the IQR outside the hinges and outliers are indicated as asterisks (outside value) or circles (far outside values).

\section{Results}

\section{Stream Habitat}

Overall median values and ranges of habitat variables for unlogged upstream 'control' sites are shown in Table 2. Significant intercorrelations were found between several habitat variable $\Delta$ values (Table 3). Positive correlations of sand/silt and superficial silt with submerged detritus $\Delta$ values may partially reflect the ability of snags to enhance sediment deposition. A positive correlation between snag volume and length of open stream $\Delta$ values results from the input of slash associated with logging immediately adjacent to the stream. A positive correlation was also found between $\Delta$ values for stream temperature and length of open stream, indicating the relationship between insolation and increases in stream temperature. The relationships between stream width (as measured at each upstream control site) and habitat and biological $\Delta$ values were examined by Spearman's rank correlation to test for the effect of stream size on the potential effects of logging. None were significant, and stream width was also not a significant covariate in any ANOVA testing for logging treatment effects on $\Delta$ values (see below).

\section{habitat variables in Tasmanian stream sites}

Significant correlations at the 0.05 level are shown in bold

\begin{tabular}{|c|c|c|c|c|c|c|c|}
\hline $\begin{array}{l}\text { Stream } \\
\text { width }\end{array}$ & $\begin{array}{l}\text { Stream } \\
\text { depth }\end{array}$ & $\begin{array}{l}\text { Algal } \\
\text { cover }\end{array}$ & $\begin{array}{l}\text { Open } \\
\text { stream } \\
\text { length }\end{array}$ & $\begin{array}{c}\text { Riffle } \\
\text { area }\end{array}$ & $\begin{array}{l}\text { Pool } \\
\text { area }\end{array}$ & Conductivity & Temperature \\
\hline
\end{tabular}

1

\begin{tabular}{|c|c|c|c|c|c|c|c|}
\hline-0.053 & 1 & & & & & & \\
\hline-0.025 & -0.145 & 1 & & & & & \\
\hline-0.004 & 0.164 & 0.341 & 1 & & & & \\
\hline 0.029 & -0.118 & -0.390 & -0.225 & 1 & & & \\
\hline-0.225 & 0.266 & 0.358 & 0.212 & -0.694 & 1 & & \\
\hline 0.164 & -0.250 & 0.079 & 0.087 & -0.108 & 0.023 & 1 & \\
\hline-0.033 & -0.252 & 0.430 & 0.374 & -0.074 & -0.090 & 0.270 & 1 \\
\hline
\end{tabular}



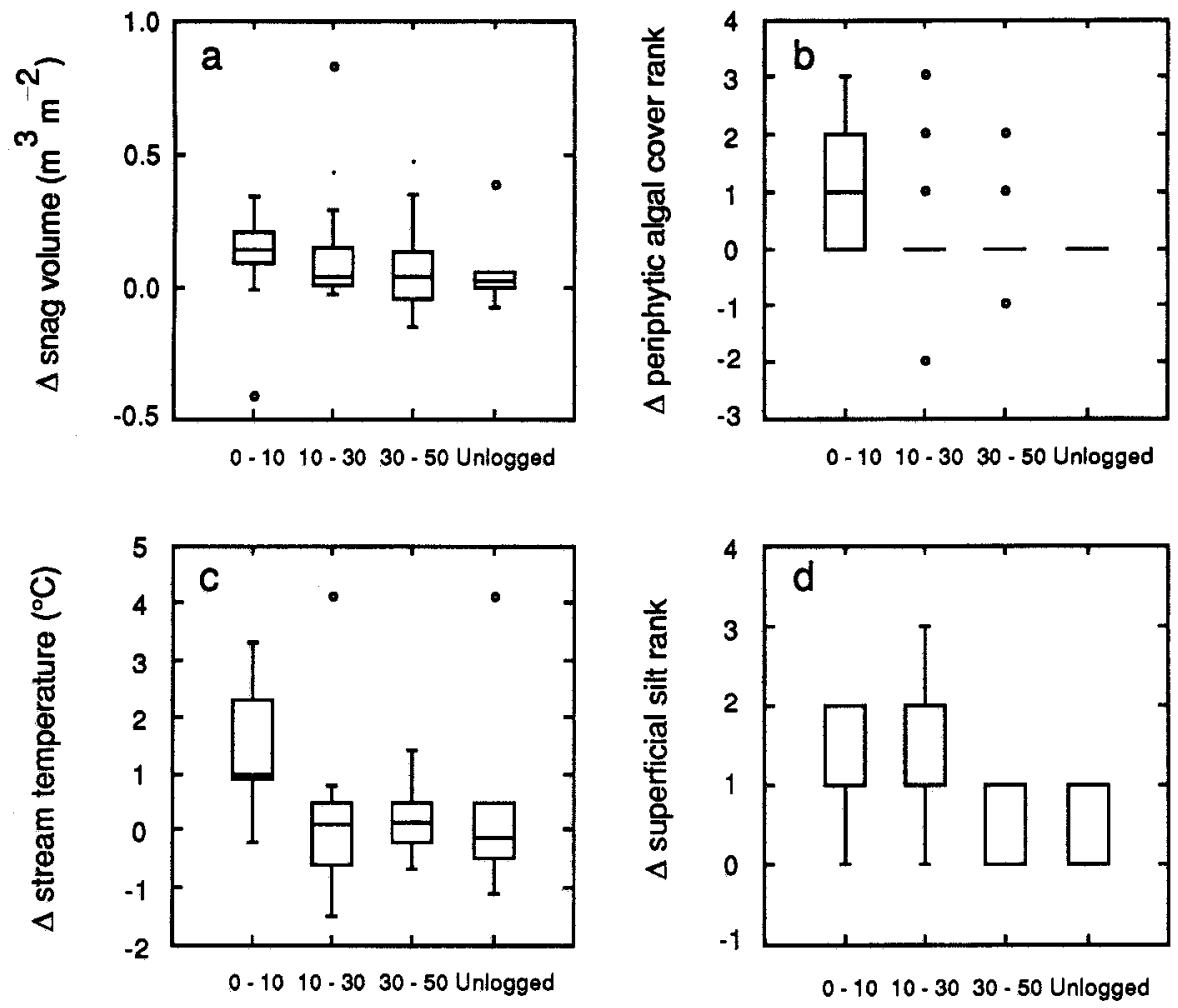

Buffer width (m)

\section{Buffer width (m)}

Fig. 2. Relationship of $\Delta$ values for (a) stream snag volume, (b) rank of periphytic algal cover, (c) stream temperature and $(d)$ stream superficial silt rank with buffer strip width.

\section{Habitat v. Buffer Width}

As $\Delta$ values for habitat variables may be related to the distances between site pairs, correlations of habitat variables and buffer width with intersite distance were examined. These were all found to be non-significant (Spearman's rank correlation, all $P>0.2$ ), and as there were no significant differences between paired sites for different treatments, distance between site pairs was not a confounding factor in this study. Similarly, there were no significant differences for any habitat variable between groups of 'control' sites upstream of logging treatments at different buffer widths (ANOVA, all $P>0.1$ ).

There were no significant correlations between any habitat variable $\Delta$ value and coupe slope, coupe age or soil erosion class. Snag volume $\Delta$ values were negatively correlated with buffer width (Spearman's rho $=-0.31, P<0.05$; Fig. $2 a$ ), indicating an increase in snag volume at sites downstream of logging treatments at small buffer widths, with a median $\Delta$ value of $0.14 \mathrm{~m}^{3} \mathrm{~m}^{-2}$ for $<10$-m buffers compared with the overall median of $0.04 \mathrm{~m}^{3} \mathrm{~m}^{-2}$ for unlogged upstream sites (Table 2). Similar correlations were found for periphytic algal cover, superficial silt and length of open stream $(-0.38,-0.40$ and $-0.46, P<0.01,0.01$ and 0.005 respectively, all $n=45$; Figs $2 b$, $2 d, 3 a$ ). Temperature $\Delta$ values for were also negatively correlated with buffer width (Spearman's rho $=-0.33, P<0.05, n=31 ;$ Fig. $2 c$ ), indicating a significant increase in temperature at sites downstream of logging treatments with small buffer widths. 


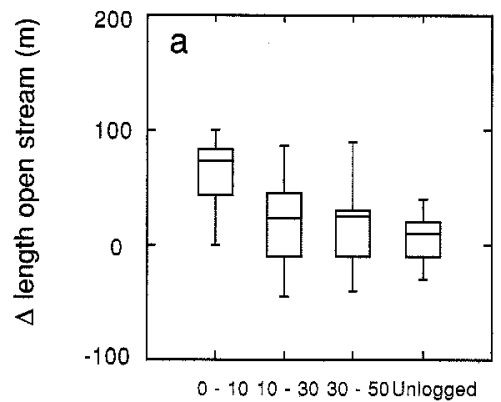

Buffer width (m)

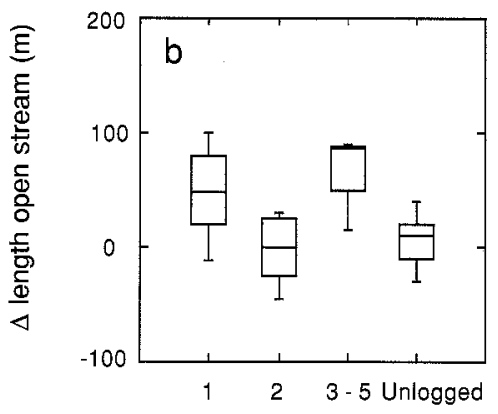

Age since logging
Fig. 3. Relationship of $\Delta$ values for length of open stream with $(a)$ buffer strip width and $(b)$ age since logging.

Differences between buffer width classes (control, 0-10, 10-30, 30-50 m, with $n=6,12,18,9$ ) were significant for several variables. Superficial silt $\Delta$ values were higher (ANOVA, $F=$ 9.152, $P<0.005$ ) for stream pairs with buffer widths of $0-10$ and $20-30 \mathrm{~m}$ than for streams with larger buffers or unlogged streams, which were not significantly different from each other (Fig. $2 d$ ). Thus, superficial silt ranks were increased downstream of these logging treatments. The median $\Delta$ value for superficial silt rank for sites logged with $<30-\mathrm{m}$ buffers was 1 , compared with the overall median of 2 for unlogged sites (Table 2). Soil erosion class, age since logging and coupe slope were not significant covariates (ANCOVA, all $P>0.2$ ) with buffer width for this variable.

Differences between both ages (ANOVA, $F=9.33, P=0.0001$ ) and buffer widths (ANOVA, $F=4.99, P=0.005$ ) were significant for length of open stream $\Delta$ values (Figs $3 a, 3 b$ ). Length of open stream $\Delta$ values were significantly higher for streams with buffer widths of $0-10 \mathrm{~m}$ than for all other stream treatments, which were not significantly different from each other (Figure $3 a$ ). Thus, logging with buffer widths of $<10 \mathrm{~m}$ caused significant increases in the length of open stream, with a median $\Delta$ value of $72.5 \mathrm{~m}$ as compared with an overall median of $40.0 \mathrm{~m}$ for unlogged sites (Table 2). Length of open stream $\Delta$ values were greater for streams with coupe ages of 1 or 3-5 years than for those of 2 years of age or unlogged (Fig. $3 b$ ). Both buffer width and soil erosion class were marginally non-significant covariates with this variable (ANCOVA, $P=0.05$ and $P=0.09$ respectively).

The negative correlation between $\Delta$ values for algal cover and buffer width (Fig. $2 b$ ) was reflected in only weak differences between buffer width treatments (ANOVA, $P=0.06$ ), possibly owing to the use of a relatively crude index of algal abundance and the high variability in site pair differences. However, inclusion of superficial silt as a covariate increased the significance of differences due to buffer width in $\Delta$ values for periphytic algal cover (ANOVA, $P<0.02$ ). The median $\Delta$ value for algal cover for sites logged with $<10-\mathrm{m}$ buffers was 1 , compared with an overall median of 2 for unlogged sites (Table 2). 
Table 4. Median and range of abundances of macroinvertebrate taxa at all sites used for assessing community responses to logging in 21 Tasmanian streams

\begin{tabular}{|c|c|c|c|}
\hline Taxon & $\begin{array}{l}\text { Median abundance } \\
\quad\left(\text { number } \mathrm{m}^{-2}\right)\end{array}$ & $\begin{array}{r}\text { Range of } \\
\text { (numb }\end{array}$ & $\begin{array}{l}\text { f abundance } \\
\text { ber } \mathrm{m}^{-2} \text { ) }\end{array}$ \\
\hline \multicolumn{4}{|l|}{ Amphipoda } \\
\hline Gammaridae & 5 & 0 & -530 \\
\hline \multicolumn{4}{|l|}{ Diptera } \\
\hline Chironomidae & 83 & 0 & -1280 \\
\hline Simulidae & 15 & 0 & -153 \\
\hline Empididae & 3 & 0 & -110 \\
\hline Tipulidae & 5 & 0 & -40 \\
\hline Athericidae & 2 & 0 & -65 \\
\hline \multicolumn{4}{|l|}{ Coleoptera } \\
\hline Elmidae (larvae) & 44 & 0 & -628 \\
\hline Elmidae (adults) & 45 & 0 & -295 \\
\hline Helodidae & 45 & 0 & -490 \\
\hline Psephenidae & 5 & 0 & -140 \\
\hline \multicolumn{4}{|l|}{ Odonata } \\
\hline Gomphidae & 0 & 0 & -30 \\
\hline \multicolumn{4}{|l|}{ Trichoptera } \\
\hline Leptoceridae & 20 & 0 & -1530 \\
\hline Conoesucidae & 6 & 0 & -580 \\
\hline Helicophidae & 31 & 0 & -300 \\
\hline Polycentropidae & 5 & 0 & -40 \\
\hline Hydrobiosidae & 30 & 0 & -135 \\
\hline Glossosomatidae & 26 & 0 & -1060 \\
\hline Hydropsychidae & 16 & 0 & -370 \\
\hline Calocidae & 3 & 0 & -140 \\
\hline Philorheithridae & 0 & 0 & -70 \\
\hline \multicolumn{4}{|l|}{ Ephemeroptera } \\
\hline Baetidae & 80 & 0 & -796 \\
\hline Leptophlebiidae & 210 & 25 & -1050 \\
\hline \multicolumn{4}{|l|}{ Plecoptera } \\
\hline Eusthenidae & 17 & 0 & -240 \\
\hline Austroperlidae & 21 & 0 & -170 \\
\hline Grypopterygidae & 35 & 0 & -433 \\
\hline Oligochaeta & 40 & 0 & -280 \\
\hline
\end{tabular}

A significant difference was found between $\Delta$ values for stream temperature at $<10-\mathrm{m}$ buffer widths (median $1.0^{\circ} \mathrm{C}$ ) and $>10-\mathrm{m}$ widths (median $-0.15^{\circ} \mathrm{C}$; Mann-Whitney $U=27.5$, $P=0.0075$ ). The overall median temperature for unlogged upstream sites was $11.0^{\circ} \mathrm{C}$ (Table 2 ), and thus logging with $<10-\mathrm{m}$ buffers caused a $10 \%$ increase in water temperature. Stream temperature $\Delta$ values for buffer widths of $10-30$ and $30-50 \mathrm{~m}$ were not significantly different from control $\Delta$ values (Fig. $2 c$ ).

The number of stream sides logged (one or two) was not a significant covariate in any ANOVA testing for logging treatment effects on $\Delta$ values.

\section{Habitat v. Logging Method}

A MANOVA was performed on all habitat variables, with logging method (cable $v$. conventional) as the treatment and buffer width as a covariate. Neither the multivariate $F$ (Pillai's criterion) nor any univariate $F$ values were significant (all $P>0.3$ ), indicating that logging method alone was not responsible for any impacts on stream habitat. 

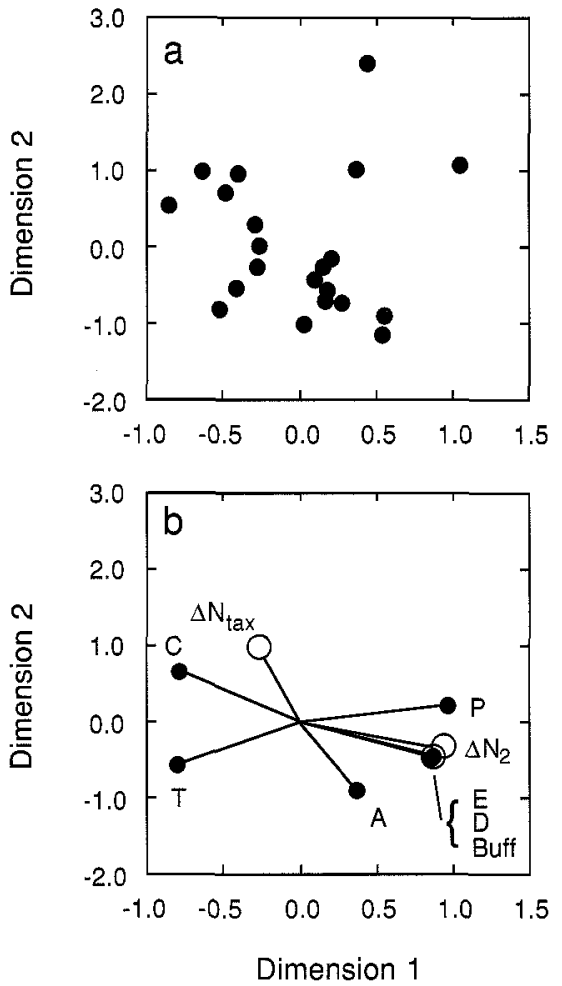

Fig. 4. Two-dimensional ordination of 21 stream site pairs by NLHMDS of a dissimilarity matrix of macroinvertebrate community $\Delta$ values: (a) stream site pair ordination plot; $(b)$ vectors for $(O)$ number of $\operatorname{taxa}\left(\Delta N_{\text {tax }}\right)$, evenness $\left(\Delta N_{2}\right)$ and buffer width (Buff) and (@) Plecoptera (P), Ephemeroptera (E), Diptera (D), Trichoptera (T), Coleoptera (C) and all taxa (A).

\section{Macroinvertebrates}

Macroinvertebrate data were collected from 21 stream site pairs at the following buffer widths: $0-10 \mathrm{~m}(n=5), 10-30 \mathrm{~m}(6), 30-50 \mathrm{~m}(5)$ and unlogged streams (5). The taxa found in this study and their median values and ranges are indicated in Table 4. NLHMDS ordination was successful (stress 0.065) for the analysis using family-level taxa in two dimensions (Fig. 4a). Differences in abundance of Ephemeroptera and Plecoptera were primarily responsible for separation of sites in the second dimension. Site scores correlated significantly with buffer strip width (PCC, Pearson's $r=0.59, P<0.01$ ) but with no other logging treatment variable (Fig. $4 b$ ). Site scores also correlated significantly (PCC, Pearson's $\mathrm{r}=0.62, P<0.01$ ) with $\Delta$ values for evenness $\left(N_{2}\right)$ but not number of taxa $\left(N_{\text {tax }}\right)$. Thus, stream invertebrate community $\Delta$ values separated in ordination space in relation to buffer width, with reduced abundances of leptophlebiids and stoneflies at buffer widths of $<30 \mathrm{~m}$. Decreased buffer width was also associated with decreases in evenness.

Differences in total abundance of macroinvertebrates between upstream and downstream site pairs were significantly positively correlated with buffer width (Spearman's rho $=0.56, P<0.01$; Fig. 5a). Thus, macroinvertebrate abundance was decreased at low buffer widths. The median total macroinvertebrate abundance for all upstream 'control' sites was $1057 \mathrm{~m}^{-2}$. The median $\Delta$ value for total macroinvertebrate abundance for sites logged with buffer widths of $<30 \mathrm{~m}$ was $-849 \mathrm{~m}^{-2}$, representing an $80 \%$ decrease in abundance.

Significant differences were found between the $\Delta$ values for abundances of both Ephemeroptera (Mann-Whitney $U=17.0, P=0.008$ ) and Plecoptera (Mann-Whitney $U=25.0$, $P=0.03$ ) at buffer strip widths of $<30 \mathrm{~m}$ and $>30 \mathrm{~m}$, indicating a significant decline in abundance of these groups at sites logged with buffers $<30 \mathrm{~m}$ wide. Median abundance of Ephemeroptera for all upstream 'control' sites was $225 / \mathrm{m}^{-2}$ and the median $\Delta$ value of $-140 \mathrm{~m}^{-2}$ for sites logged with 

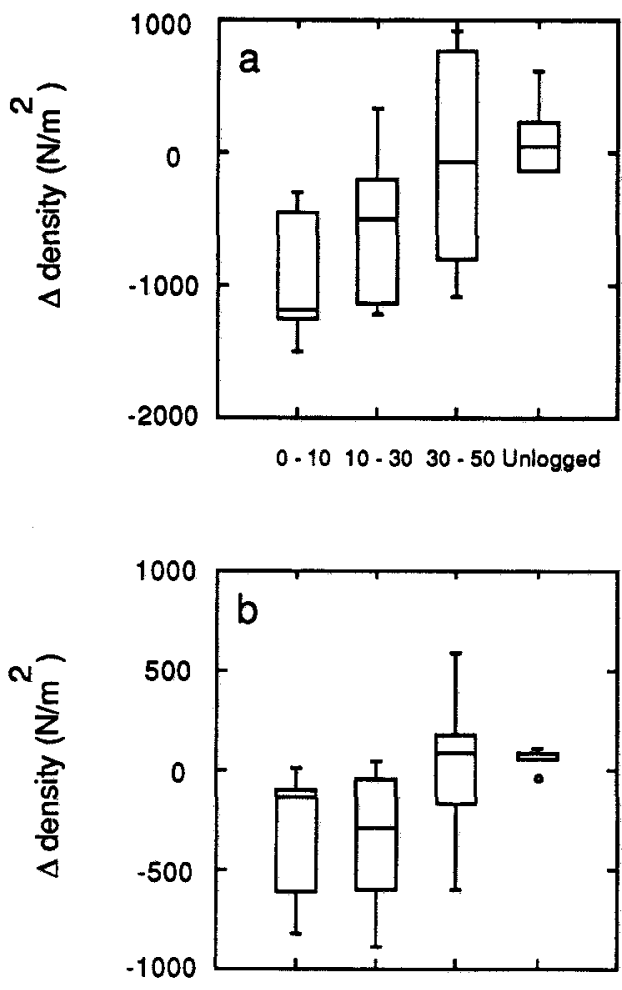

$0-1010-3030-50$ Unlogged

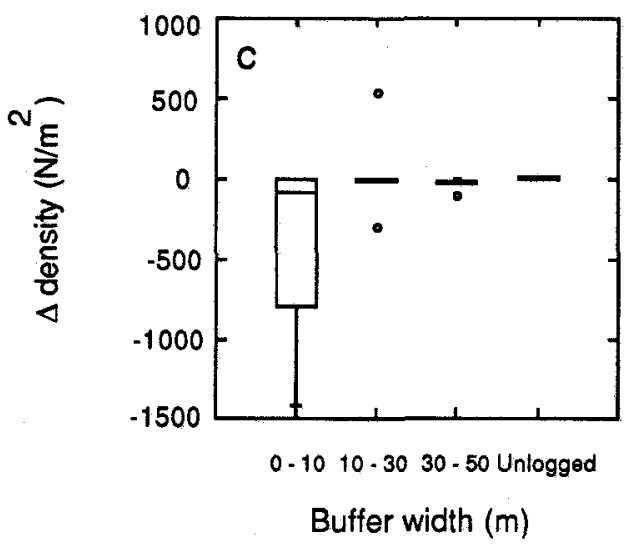

Fig. 5. Relationship of $\Delta$ values for the density of $(a)$ all stream macroinvertebrates, $(b)$ mayflies (Ephemeroptera) and $(c)$ leptocerid caddisflies with buffer strip width.

buffers of $<30 \mathrm{~m}$ width therefore represents a $62 \%$ decrease in abundance (Fig. $5 b$ ). The median abundance of Plecoptera for all upstream 'control' sites was $80 \mathrm{~m}^{-2}$, and the median $\Delta$ value for sites logged with buffers of $<30 \mathrm{~m}$ width represents a $34 \%$ decrease in abundance.

Within the Ephemeroptera, only leptophlebiids showed a significant response to buffer widths of $<30 \mathrm{~m}$ (Mann-Whitney $U=4.0, P=0.0005$ ), with $\Delta$ values being significantly lower and negative for buffer widths of $<30 \mathrm{~m}$ and with a median abundance of $137 \mathrm{~m}^{-2}$ representing a $67 \%$ decrease in abundance from an overall median of $205 \mathrm{~m}^{-2}$ for unlogged upstream 'control' sites. Although total abundance of Plecoptera showed a significant response to buffer width, differences in $\Delta$ values for the most abundant families, the austroperlids and eustheniids, 

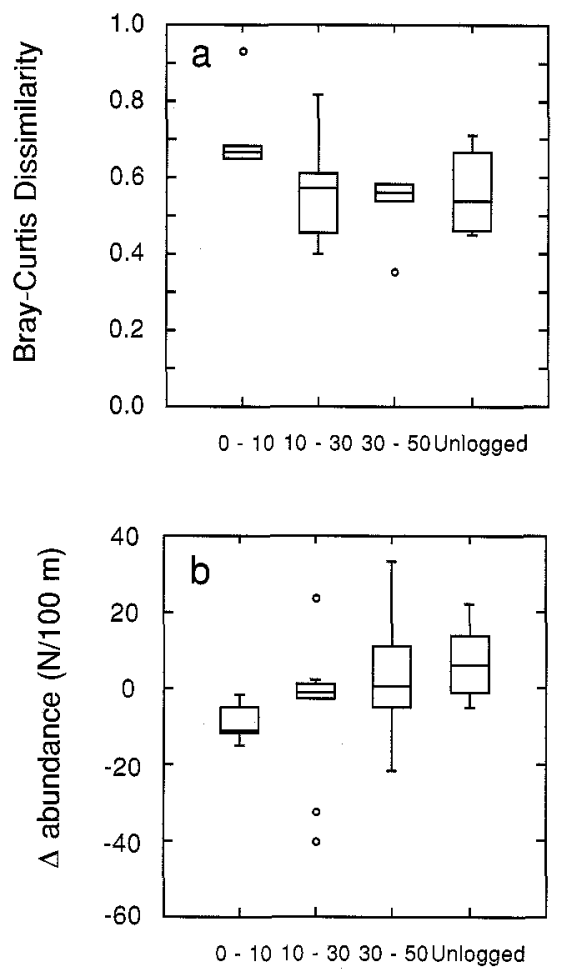

Buffer width (m)
Fig. 6. Relationship of (a) macroinvertebrate community dissimilarities and $(b) \Delta$ values for brown trout (Salmo trutta) abundance of stream site pairs with buffer strip width.

were non-significant $(P<0.1)$. Leptocerid Trichoptera were also reduced in abundance by $13 \%$ from a median abundance of $125 \mathrm{~m}^{-2}$ by logging with buffers $<30 \mathrm{~m}$ in width, but differences in this study were marginally non-significant (ANOVA, $F=3.72, P=0.06$; Fig. $5 c$ ).

Kruskal-Wallis ANOVA on the Bray-Curtis dissimilarity measures for site pairs demonstrated a significantly (Mann-Whitney $U=14, P=0.032$ ) greater dissimilarity between sites logged with buffers of $0-10 \mathrm{~m}$ width than for all other site pairs (logged or unlogged; Fig. 6a).

\section{Fish}

Four fish species were recorded during sampling (Salmo trutta, Anguilla australis, Galaxias brevipinnis, Gadopsis marmoratus), but the native species were either too low in abundance or present at insufficient sites to allow evaluation of responses to logging. Only brown trout (Salmo trutta Rich.) were found at sufficient site pairs (27) to merit data analysis. These site pairs had the following buffer widths: $0-10 \mathrm{~m}(n=5), 10-30 \mathrm{~m}(9), 30-50 \mathrm{~m}(7)$ and unlogged streams (6). Mean abundances and biomass values for all sites were $22.4(s . d .=14.64)$ per 100 $\mathrm{m}$ and 34.5 (s.d. $=27.2$ ) $\mathrm{kg} \mathrm{ha}^{-1}$ respectively. A significant positive correlation was found between $\Delta$ values for numerical abundance and buffer width (Spearman's rho $=0.42, P<0.05$ ) but not for biomass. No single size class was responsible for this relationship, although the correlation for fish $10-20 \mathrm{~cm}$ long approached significance $(0.05<P<0.1)$.

A statistically significant decrease in $\Delta$ values for abundance of $S$. trutta was found for streams with buffer widths of $<30 \mathrm{~m}$ (ANOVA, $F=4.24, P=0.05$; Fig. $6 b$ ), indicating a decline in abundance at sites downstream of areas logged with buffers $<30 \mathrm{~m}$ wide compared with sites downstream of unlogged or $<30$-m-buffered logged areas. This represents a decrease 
from a median of 5.1 for $\Delta$ in $S$. trutta abundance per $100 \mathrm{~m}$ for streams with $>30 \mathrm{~m}$ buffer width to -6.9 for logged streams with $<30 \mathrm{~m}$ buffer width. There were no differences in trout abundance $\Delta$ values between unlogged streams and streams logged with buffers of $>30 \mathrm{~m}$. The overall median trout abundance for control sites was 22 per $100 \mathrm{~m}$. There was therefore a reduction in trout abundance of $54 \%$ associated with logging with buffers $<30 \mathrm{~m}$ in width.

\section{Discussion}

In this study, logging was associated with a number of impacts on stream habitat variables and on macroinvertebrate and fish populations. The width of the riparian forest 'buffer' strip was a dominant factor in determining the degree of impact, with little effect of coupe slope or soil type. Time after logging has been shown to have a significant impact on changes to catchment yield and stream hydrology (Cornish 1993) and to yield of sediment (Grayson et al. 1993) and infiltration of sediment into stream beds (Davies and Nelson 1993). Time was not, however, a significant factor or covariate in the present study, suggesting that significant recovery from logging impacts did not occur within a period of three to five years. A significant relationship found in the present study between length of open stream and time after logging was possibly confounded by significant differences in ages of coupes sampled with differing buffer widths (ANOVA, $P<0.05$ ).

Habitat variables affected by logging were: superficial silt cover on riffles, length of open stream, water temperature, periphytic algal cover and snag volume. The increase in the median $\Delta$ by 1 rank for periphytic algal and superficial silt cover on riffles at sites logged with buffers of $<10 \mathrm{~m}$, when compared with unlogged 'control' site median rank values of 2 (Table 2), indicates an approximate doubling in percentage cover for these two variables. Snag volume, length of open stream and stream temperature were increased by factors of $420 \%, 280 \%$ and $10 \%$ respectively by logging with buffers of $<10 \mathrm{~m}$. Macroinvertebrates decreased in abundance with buffer strip width, with leptophlebiid mayflies and stoneflies being most affected at widths $<30 \mathrm{~m}$. Brown trout abundance was also decreased by around $50 \%$ in streams logged at $<30 \mathrm{~m}$ width. The degree of impact was therefore dependent on buffer width, with the intensity and number of variables responding being greatest when riparian vegetation was severely damaged or effectively removed ( $0-10 \mathrm{~m}$ buffer width). Stream temperatures were significantly enhanced (by $1.2^{\circ} \mathrm{C} \mathrm{km}^{-1}$ ) only when buffer widths fell below $10 \mathrm{~m}$, presumably because of the almost complete removal of shading from riparian vegetation (Ringler and Hall 1975; Murphy et al. 1986).

Several published studies address the issue of buffer widths and stream habitat and biotic impacts, either directly or indirectly. Borg et al. (1988) described significant deleterious impacts on stream channels and water quality (algal blooms) when buffer strips were completely removed, as opposed to streams with 100 -m buffers. Culp and Davies (1983) examined the impacts resulting from logging with buffers $\leq 10 \mathrm{~m}$ in width. They noted that although stream bank destabilization was reduced, significant reductions occurred in macroinvertebrate densities and leaf litter inputs. Murphy et al. (1986), in a study assessing the impact of logging on salmonid populations in Alaska, found that streams in clearfelled areas (buffer widths from 0 to $10 \mathrm{~m}$ ) had higher densities of periphyton, lower channel stability and less canopy cover, pool volume, debris and undercut banks than did reaches in old-growth forest. There were no consistent differences in these variables between buffered reaches and old-growth reaches. They attributed this to wide variations associated with the wide range of buffer widths and integrities on the buffered streams they studied. Several buffers ranged to $>100 \mathrm{~m}$, and the remainder had a mean of $45 \mathrm{~m}$ width. Many suffered from selective logging or the impacts of blow-down-a significant phenomenon in the management of coniferous forest buffers in the north-western USA but not in Australia. Newbold et al. (1980) examined the impact of logging on Californian stream macroinvertebrates in relation to buffer strip width, which ranged from 3-60 m. Reaches with buffers of $\geq 30 \mathrm{~m}$ were not significantly different from controls in terms of diversity, similarity (measured as Euclidian distance) or 
densities of individual taxa. Reaches without buffers had higher densities of tolerant macroinvertebrate taxa (e.g. Chironomidae, Baetis) and lower diversities. Reaches with buffer widths of $<30 \mathrm{~m}$ were significantly different by Euclidian distance, but not by other variables owing to high variability in buffer width and integrity. Noel et al. (1986) found that streams with buffers 8-9 $\mathrm{m}$ in width had higher periphytic densities, with a greater dominance of chlorophytes, as well as greater densities of Baetis and chironomids, two to three years after logging. They associated these changes with higher light intensities and water temperatures resulting from reduced canopy cover. The findings of these studies, as well as the earlier literature on sedimentation in relation to buffer widths (Clinnick 1985), suggest that the intensities and types of logging impact on streams are directly related to buffer width.

Small buffers ( $\leq 10 \mathrm{~m}$ wide) do not significantly protect a stream from impact, particularly in relation to canopy modification and consequent changes in algal, macroinvertebrate and fish biomass and diversity. Larger buffers (30-100 $\mathrm{m}$ wide) appear to provide adequate protection. The present study confirms the earlier finding of Newbold et al. (1980) that buffers $\geq 30 \mathrm{~m}$ in width appear to provide protection from short-term impacts despite the distinctly different stream and forest types and geomorphology of the terrain examined in the two studies.

Published Australian studies of impacts from logging operations on stream habitats and biota are few (Richardson 1985; Borg et al. 1988; Growns and Davis 1991). Growns and Davis (1991), in the only intensive study of the effects of logging on stream biota in Australia to date, found that despite evidence for differences in macroinvertebrate community composition (primarily identified to species level) between logged and unlogged streams eight years after logging, there were no significant differences in richness or abundance. The influence of season and location, combined with the small number of treatment replicates, may have precluded observation of real differences in richness or abundance (the combined problems of confounding and Type II error). Compositional differences between clearfelled, buffered (100 $\mathrm{m}$ width) and unlogged streams were related to the abundance of fine and coarse particulate organic matter (FPOM, CPOM) and conductivity. Inputs of organic matter were associated with material felled and disturbed in the stream in the clearfelled areas. It should be noted that despite the apparent ameliorative actions of $100-\mathrm{m}$ buffers in the study reported by Growns and Davis (1991), macroinvertebrate community composition in buffered streams was intermediate between unlogged and clearfelled streams. This suggests that even logging within 100-m buffers may still cause community responses at the species level. Sensitive tests of the effects of land use on stream aquatic fauna may require taxonomic discrimination to species level, although family level identification has been shown to be sufficient to allow consistent site classification in relation to such impacts (Marchant 1990). In the present study, the identification of fauna to lower than family level was precluded in part by resource limitations, but also by the high local endemicity, particularly of the Tasmanian aquatic insect fauna (Neboiss 1977; Hynes 1989), which would reduce the degree of replication per taxon in the detection of logging impacts owing to the necessarily wide geographical distribution of study streams.

In the present study, logging caused significant impacts on Tasmanian stream habitats, invertebrates and fish, but only for those streams with buffer strips less than $30 \mathrm{~m}$ in width. This finding is consistent with a review by Clinnick (1985) on buffer strip management, in which the majority of the literature reviewed concerned studies on stream sedimentation and soil movement. All streams in the present study were classified as Class 2 streams, according to the Tasmanian Forest Practices Code (Anon. 1993), and therefore should have buffers of at least $30 \mathrm{~m}$ in width.

The present study therefore supports the use of buffers $\geq 30 \mathrm{~m}$ in width to minimize shortterm impacts on streams. However, several caveats should be noted. Firstly, this study focused on 'snapshot' assessments of stream condition during summer base flows. The impact of logging on water quality was not examined, and it is possible that larger buffer widths may be needed in some or many situations to protect streams from enhanced suspended sediment and/or nutrient loads associated with substantial storm events. 
Secondly, it was not difficult to find study streams with buffers less than $30 \mathrm{~m}$, despite logging having been conducted during the period in which the Forest Practices Code was in use by the forestry industry. This suggests that compliance may be a significant issue in forest management. It should be noted, however, that within the Tasmanian forest industry management structure, there is a substantial programme of training and review in relation to the Code that is actively improving awareness and adoption of the recommendations of the Code (B. Whitte, Forestry Commission Tasmania, personal communication).

Finally, width is not the only factor that determines the efficacy of buffers to protect streams from land-use activities. Interception of surface runoff and the degree of impact on the light climate and temperature of a stream are also dictated by buffer vegetation characteristics. This is also a factor in the interception of pesticide drift from forestry spraying operations (Barton and Davies 1993). Care must be taken to preserve the integrity of the buffer as well as its extent and width (Clinnick 1985). Penetration of the buffer during logging operations or inappropriate enhancement of slope drainage may significantly increase the potential for surface water to drain through the buffer unimpeded, thereby increasing the opportunity for sediment input to streams. These factors need more detailed evaluation. Certainly, buffer width and quality are interrelated, but at the coarse scale of the present study, width appears to be a dominant factor.

\section{Acknowledgments}

This work was conducted at the Inland Fisheries Commission, Tasmania, the staff of which assisted with the field programme, most notably Brett Mawbey and Stuart Chilcott. Thanks are due to David Ratkowsky and Leon Barmuta for advice on analysis and to an anonymous reviewer for valuable comments. Support from staff of the Tasmanian Forestry Commission and North Forest Products in the form of advice, site information and access was also appreciated. This study was supported by a grant from the Tasmanian Forest Research Council.

\section{References}

Anon. (1993), 'Forest Practices Code.' (Forestry Commission: Hobart, Tasmania, Australia.)

Barton, J. L., and Davies, P. E. (1993). Buffer strips and streamwater contamination by atrazine and pyrethroids aerially applied to Eucalyptus nitens plantations. Australian Forestry 56, 201-10.

Belbin, L. (1993). 'PATN—Pattern Analysis Package'. (CSIRO Division of Wildlife and Rangelands Research: Canberra.)

Blackie, J. R., Ford, E. D., Horne, J. E. M., Kinsman, D. J. J., Last, F. T., and Moorhouse, P. (1980). Environmental effects of deforestation: an annotated bibliography. Freshwater Biological Association Occasional Publication No. 10.

Borg, H., Hordacre, A., and Batini, F. (1988). Effects of logging in stream and river buffers on watercourses and water quality in the southern forest of Western Australia. Australian Forestry 51, 98-105.

Cameron, A. L., and Henderson, L. E. (1979). 'Environmental Considerations for Forest Harvesting,' (CSIRO: Melbourne.)

Campbell, I. C., and Doeg, T. J. (1989). Impact of timber harvesting and production on streams: a review. Australian Journal of Marine and Freshwater Research 40, 519-39.

Clinnick, P. F. (1985). Buffer strip management in forest operations: a review. Australian Forestry 48 , $34-45$.

Cornish, P. M. (1993). The effects of logging and forest regeneration on water yields in a moist eucalypt forest in New South Wales, Australia. Journal of Hydrology Amsterdam 150, 301-42.

Culp, J. M., and Davies, R. W. (1983). An assessment of the effect of streambank clearcutting on macroinvertebrate communities in a managed watershed. Canadian Technical Report of Fisheries and Aquatic Sciences No. 1208.

Davies, P. E., and Nelson, M. (1993). The effect of steep slope logging on fine sediment infiltration into the beds of ephemeral and perennial streams of the Dazzler Range, Tasmania, Australia. Journal of Hydrology (Amsterdam) 150, 481-504. 
Doeg, T. J., and Koehn, J. D. (1990a). The effects of forestry practices on fish, aquatic macroinvertebrates and water quality: a bibliography. Victorian Department of Conservation, Forests and Lands SSP Technical Report No. 3.

Doeg, T. J., and Koehn, J. D. (1990b). A review of Australian studies on the effects of forestry practices on aquatic values. Victorian Department of Conservation, Forests and Lands SSP Technical Report No. 5.

Faith, D. P., and Norris, R. H. (1989). Correlation of environmental variables with patterns of distribution and abundance of common and rare freshwater macroinvertebrates. Biological Conservation $\mathbf{5 0}$, $77-98$.

Faith, D. P., Minchin, P. R., and Belbin, L. (1987). Compositional dissimilarity as a robust measure of ecological distance. Vegetatio 68, 57-68.

Graynoth, E. (1979). Effects of logging on stream environments and faunas in Nelson. New Zealand Journal of Marine and Freshwater Research 13, 79-109.

Grayson, R. B., Haydon, S. R., Jayasuriya, M.D.A., and Finlayson, B.L. (1993). Water quality in mountain ash forests-separating the impacts of roads from those of logging operations. Journal of Hydrology (Amsterdam) 150, 459-80.

Growns, I. O,, and Davis, J. A. (1991). Comparison of macroinvertebrate communities in streams in logged and undisturbed catchments 8 years after harvesting. Australian Journal of Marine and Freshwater Research 42, 689-706.

Helsel, D. R., and Hirsch, R. M. (1992). 'Statistical Methods in Water Resources.' Studies in Environmental Science No. 49. (Elsevier: Amsterdam.)

Higgins, P. J. (1985). An interactive computer program for population estimation using the Zippin method. Aquaculture and Fisheries Management 1, 287-95.

Hynes, H. B. N. (1989). Tasmanian Plecoptera. Australian Society for Limnology Special Publication No.8. $81 \mathrm{pp}$.

Lisle, T. E. (1986). Effects of woody debris on anadromous salmonid habitat, Prince of Wales Island, southeast Alaska. North American Journal of Fisheries Management 6, 538-50.

Marchant, R. (1989). A subsampler for samples of benthic invertebrates. Australian Society for Limnology Bulletin No.12, 49-52.

Marchant, R. (1990). Robustness of classification and ordination techniques applied to macroinvertebrate communities from the La Trobe River, Victoria. Australian Journal of Marine and Freshwater Research 41, 493-504.

Murphy, M. L., Hawkins, C. P., and Anderson, N. H. (1981). Effects of canopy modification and accumulated sediment on stream communities. Transactions of the American Fisheries Society $\mathbf{1 0 0}$, 469-78.

Murphy, M. L., Heifetz, J., Johnson, S. W., Koski, K. V., and Thedinga, J. F. (1986). Effects of clear-cut logging with and without buffer strips on juvenile salmonids in Alaskan streams. Canadian Journal of Fisheries and Aquatic Sciences 43, 1521-33.

Neboiss, A. (1977). A taxonomic and zoogeographic study of Tasmanian caddisflies. Memoirs of the National Museum of Victoria 38, 1-128.

Newbold, J. D., Erman, D. C., and Roby, K. B. (1980). Effects of logging on macroinvertebrates in streams with and without buffer strips. Canadian Journal of Fisheries and Aquatic Sciences 37, 1076-85.

Noel, D. S., Martin, C. W., and Federer, C. A. (1986). Effects of forest clearcutting in New England on stream macroinvertebrates and periphyton. Environmental Management 10, 661-70.

Richardson, B. A. (1985). The impact of forest road construction on the benthic invertebrate and fish fauna of a coastal stream in southern New South Wales. Australian Society for Limnology Bulletin No.10, 65-88.

Ringler, N. H., and Hall, J. D. (1975). Effects of logging on water temperature and dissolved oxygen in spawning beds. Transactions of the American Fisheries Society 104, 111-21.

Tabachnik, B. G., and Fidell, L. S. (1989). 'Using Multivariate Statistics.' 2nd edn. (Harper and Row: New York.)

Wilkinson, L., Hill, M., and Vang, E. (1992). 'SYSTAT: Statistics.' Version 5.2. (SYSTAT, Inc.: Evanston, Illinios.)

Zar, J. H. (1984). 'Biostatistical Analysis.' 2nd edn. (Prentice-Hall: London.)

Zippin, C. (1958). The removal method of population estimation. Journal of Wildlife Management 22 $82-90$. 